OPEN ACCESS

Edited by:

José Manuel García-Fernández, University of Alicante, Spain

Reviewed by:

Federico Pulido Acosta,

University of Granada, Spain

Ángel De-Juanas,

National University of Distance

Education (UNED), Spain

*Correspondence:

Ramón García-Perales

Ramon.GarciaPerales@uclm.es

Specialty section:

This article was submitted to

Educational Psychology,

a section of the journal

Frontiers in Psychology

Received: 28 May 2020

Accepted: 07 July 2020

Published: 07 August 2020

Citation:

Palomares-Ruiz A and García-Perales R (2020) Math

Performance and Sex: The Predictive Capacity of Self-Efficacy, Interest and Motivation for Learning

Mathematics.

Front. Psychol. 11:1879. doi: 10.3389/fpsyg.2020.01879

\section{Math Performance and Sex: The Predictive Capacity of Self-Efficacy, Interest and Motivation for Learning Mathematics}

\author{
Ascensión Palomares-Ruiz and Ramón García-Perales* \\ Department of Pedagogy, Faculty of Education of Albacete, University of Castilla-La Mancha, Albacete, Spain
}

Differences between the sexes in education is something of particular interest in much research. This study sought to investigate the possible differences between the sexes in math performance, and to deeply examine the causal factors for those differences. Beginning from the administration of the BECOMA-On (Online Evaluation Battery of Mathematics Skills) to 3,795 5th year primary students aged 10-11, in 16 Spanish autonomous communities and the 2 autonomous cities of Ceuta and Melilla. The results for each sex were compared to their perceptions of self-efficacy about completing the test items, and with their interest in and motivation for mathematics. Statistically significant differences were seen in the variables examined. The boys were generally more engaged with science and technical subjects. Generalizing from studies such as this aims to more thoroughly explore, and improve this situation.

Keywords: math performance, sex, self-efficacy, interest and motivation for math, primary education

\section{INTRODUCTION}

Inequality between the sexes in education is an enormously important issue for society as a whole, not only for those working in the field. Its importance goes beyond the educational arena and is manifested in power dynamics and decision-making in various contexts. The origins of these inequalities may be multidimensional, such as traits, behaviors, and identities determined by socialization processes (Hadjar et al., 2014; García-Perales, 2016; Ministerio de Educación y Formación Profesional, 2019b) causing internal dissonance, on occasion led by undervaluing talent and potential (Pomar et al., 2009).

In this study, we focus on science and technical disciplines, women are underrepresented in these fields (Lehman et al., 2017; Botella et al., 2019; McCullough, 2020), more specifically on math. We aim to thoroughly examine the reasons for differences between the sexes in this area, looking into possible causal factors. Various studies have concluded that boys get better results in tests of math performance (Bennett, 1997; Furnham et al., 1999; Pasarín et al., 2004; Chan, 2006; Sánchez et al., 2008; Llor et al., 2012; Instituto Nacional de Evaluación Educativa, 2013; Ministerio de Educación y Formación Profesional, 2019b), and that there are differences in scientific and mathematical reasoning that favor boys and men (Fox and Denham, 1974; Beltrán and Pérez, 1994; Pasarín et al., 2004; Barbero et al., 2007; Suberviola, 2012). This leads to the necessary interpretation beyond the 
educational arena that, as stated in PISA 2018, "there is a deficit of representation of girls among students with the highest levels of performance in science and mathematics may explain, at least in part, the persistent gender gap in science, technology, engineering, and mathematics (STEM) courses, fields which are among the best paid occupations" (Ministerio de Educación y Formación Profesional, 2019b, p. 85).

From early ages, boys and girls receive the same math instruction, allowing them to assimilate fundamental algorithms to structure their math reasoning in order to be able to apply it to everyday problems. Modifying the teaching and learning processes to their potentials, interests, and motivations helps to prevent the frustration, boredom, and even rejection that the subject sometimes causes in students (González, 2019). Teacher training for the prevention of these attitudes is essential (Nortes and Nortes, 2020). The differences between the sexes in this area cannot be explained by the existence of innate differences of ability (Ministerio de Educación y Formación Profesional, 2019b).

A favorable disposition toward learning math is fundamental, and many national and international organizations have stressed the importance of working on these attitudes in the classroom (Unión Europea, 2004; Ministerio de Educación, Cultura y Deporte, 2014; Ministerio de Educación y Formación Profesional, $2019 b)$. This has also been reinforced by various studies (Cueli et al., 2013; Mato et al., 2014), with the teacher having a prominent role as one who understands these internal processes (Muñoz and Mato, 2008; Tourón et al., 2012). According to this variable, PISA 2012, the last version to focus on the specific evaluation of mathematics, concluded that pupils' interest in learning math was low, they did not enjoy their learning very much. Girls' progress in this area was hindered by anxiety and a lack of confidence (Instituto Nacional de Evaluación Educativa, 2013), and by the different types of education they received depending on their models of socialization both in and outside the family environment (Ministerio de Educación y Formación Profesional, 2019b). Nonetheless, the gap between boys and girls has narrowed in each edition of PISA in Spain (Ministerio de Educación y Formación Profesional, 2019b). Logically, attention must be paid to the math affective domain (Palacios et al., 2014). The analysis of these attitudes is fundamental in more capable students because "weaknesses in attitudes toward the study of math not only affect lower performing students or schools, many students who are relatively high achieving are slowed down by their negative attitudes toward math" (Muñoz and Mato, 2008, p. 224).

Students with greater potential for math show, even from the beginning of their learning, intense activity and commitment to tasks, rapid understanding of concepts and algorithms, high capacity for abstraction, high flexibility of thought, and elevated interest and motivation (Kruteskii, 1976; Benavides, 2008; ReyesSantander and Karg, 2009). The numbers of detected cases of highly intellectually capable female students is lower than for their male peers. By way of illustration, this situation is clear from the national data for Spanish schoolchildren in school year 2017/8, the most recent year for which official data is available (Ministerio de Educación y Formación Profesional, 2020): Table 1.
TABLE 1 | Prevalence of highly intellectually capable students in Spain by sex

\begin{tabular}{|c|c|c|c|c|c|}
\hline \multirow[t]{2}{*}{ Region } & \multirow{2}{*}{$\begin{array}{l}\text { Total high } \\
\text { capacity }\end{array}$} & \multicolumn{4}{|c|}{ Boys girls } \\
\hline & & $n$ & $\%$ & $n$ & $\%$ \\
\hline Andalucía & 14420 & 8819 & 61.16 & 5601 & 38.84 \\
\hline Aragón & 478 & 368 & 76.99 & 110 & 23.01 \\
\hline Asturias & 1087 & 756 & 69.55 & 331 & 30.45 \\
\hline Baleares & 1132 & 762 & 67.31 & 370 & 32.69 \\
\hline Canarias & 2235 & 1425 & 63.76 & 810 & 36.24 \\
\hline Cantabria & 138 & 104 & 75.36 & 34 & 24.64 \\
\hline Castilla and León & 742 & 564 & 76.01 & 178 & 23.99 \\
\hline Castilla La Mancha & 510 & 370 & 72.55 & 140 & 27.45 \\
\hline Cataluña & 2108 & 1392 & 66.03 & 716 & 33.97 \\
\hline Comunidad Valenciana & 1637 & 1142 & 69.76 & 495 & 30.24 \\
\hline Extremadura & 331 & 248 & 74.92 & 83 & 25.08 \\
\hline Galicia & 1833 & 1223 & 66.72 & 610 & 33.28 \\
\hline Madrid & 2371 & 1621 & 68.37 & 750 & 31.63 \\
\hline Murcia & 3755 & 2341 & 62.34 & 1414 & 37.66 \\
\hline Navarra & 410 & 287 & 70.00 & 123 & 30.00 \\
\hline País Vasco & 564 & 407 & 72.16 & 157 & 27.84 \\
\hline La Rioja & 350 & 245 & 70.00 & 105 & 30.00 \\
\hline Ceuta & 9 & 7 & 77.78 & 2 & 22.22 \\
\hline Melilla & 3 & 3 & 100.00 & 0 & 0.00 \\
\hline Spain & 34113 & 22084 & 64.74 & 12029 & 35.26 \\
\hline
\end{tabular}

Authors creation using statistics from Ministerio de Educación y Formación Profesional (2020).

As Table 1 makes clear, of the 34,113 students identified as highly intellectually capable in Spain, 22,084 (64.74\%) were boys compared to 12,029 (35.26\%) girls. In the autonomous communities, Andalucía was the most equal region with 8,819 (61.6\%) boys and 5,601 (38.84\%) girls, whereas Aragón exhibited the greatest differences with 368 (76.99\%) boys and 110 (23.01\%) girls. Despite these differences in numbers between the sexes, there are studies that have shown that there are no differences in high abilities between boys and girls (Organización para la Cooperación y el Desarrollo Económico, 2009; Jiménez et al., 2010; Jiménez and Baeza, 2012). In this regard, Pérez and Díaz (1994, p. 110) noted that "studies that pose the hypothesis of a sex-linked hereditary factor for mathematical or spatial aptitude, or a different lateral specialization in the brain for men and women are not very substantial." In addition, there are studies which noted that girls suffered from more prejudice in the diagnostic process for giftedness (Kerr, 2000; Landau, 2003; Jiménez, 2014), existing stereotypes that influence their academic and professional choices in education (Bian et al., 2017) and showing higher levels of emotional problems with respect to gifted boys (Huang et al., 2020). Therefore, there is a need to give a high profile to giftedness, regardless of sex (Mandelman et al., 2010; Hernández and Gutiérrez, 2014; Jaime and Gutiérrez, 2017; García-Perales and Almeida, 2019).

In summary, in this study we aimed to show the results achieved by students participating in the BECOMA-On according to sex, relating the scores to students own perceptions of self-efficacy in completing the test battery, and their interest in and motivation for math. This study uses a contextual framework 
in order to provide guidance for setting the most egalitarian educational policies possible.

\section{MATERIALS AND METHODS}

This was a ex post facto study which attempted to analyze the relationships between a series of quantitative data.

\section{Participants}

According to the statistics from MEFP for the 2018/19 school year, the time of the study, $51.7 \%$ of schoolchildren were boys, and $48.3 \%$ were girls. The data for primary schoolchildren was $51.6 \%$ boys, and $48.4 \%$ girls (Ministerio de Educación y Formación Profesional, 2020).

The main sample for the study was selected from 147 infant and primary schools from 16 autonomous communities, and 2 autonomous cities. The participating schools were both publicly funded and private or independent, and in both urban and rural areas. The sample selection method was not random, each autonomous community selected the participating schools in their areas. The distribution of the study sample according to their sex was as follows: male 2002 or $52.75 \%$ and female 1793 or $47.25 \%$.

\section{Variables}

The main variable in the study was math performance via the BECOMA-On test. This construct has its educational basis in the elements or thinking that allow a subject to deal with dayto-day situations, and assessing how that contributes to social and cultural progress. It is also based on subjects' understanding of how mathematical algorithms work, modifying them to each individual situation.

Two additional variables were considered:

- Self-efficacy in completing the test battery: this was systematized from 0 , the lowest value, to 10 , the highest value. It is a relative belief in the subjects' ability to complete the test battery, based on feelings, actions, and thoughts. The following question has been collected from schoolchildren once the battery has been completed: "How did the test go? Mark an option from 0 to 10, with 0 being the lowest score and 10 being the highest. It indicates only one option."

- Interest and motivation toward mathematics as a subject: categorized from 0 (lowest value) to 10 (highest value). This variable has an impact on the students' intrinsic motivation for the subject, affecting their effort and involvement, and thus their academic performance. After completing the instrument, students have been asked the following questions: "What is your interest and motivation toward the Mathematics area? Mark an option from 0 to 10, with 0 being the lowest score and 10 being the highest. It indicates only one option."

\section{Instrument}

BECOMA-On is an instrument own creation for the online evaluation of math performance in 5th-year primary students, aged about 10-11. It has 30 items spread over 7 Evaluation Tests (ET): Mathematical interpretation (ET1, items 1-5), Mental arithmetic (ET2, items 6-11), Geometric properties (ET3, items 12 and 13), Logical numerical series (ET4, items 14-19), Discovering algorithms (ET5, items 20 and 21), Conventional units (ET6, items 22-27), and Logical series of figures (ET7, items 28-30). Each item is scored as 0 , 1 , or 2 , where 0 means incorrect, 1 means partially correct, and 2 means correct. The test scores range from 0 to 60 . The reliability index for the original battery was 0.83 and the validity indices were between 0.78 and 0.86 .

This instrument seeks to produce both a qualitative and quantitative evaluation of the students' math performance. Using the results, students are placed in one of 7 hierarchical performance levels with different qualitative characteristics, from poorer to better mastery of the subject. The instrument is applied to class groups online, and takes about $45 \mathrm{~min}$ to complete.

\section{Procedure}

The study was carried out during February 2019. The schools selected were charged with administering the instrument, and in particular with explaining each test, demonstrating examples, and monitoring the time. Prior to the application, participating teachers were given specific training in the administration and content of the instrument. All of the variables used in the study were collected at the same time as the application of the test battery. In the analysis of the results, descriptive statistics and the mean comparison $t$-test were mainly used. For the treatment of the results, the SPSS V24 program has been used.

\section{RESULTS}

The results are given below in three sections: the relationship between the BECOMA-On results and sex, the relationship between the BECOMA-On results, sex, and self-efficacy regarding the test battery and the relationship between the BECOMA-On results, sex, and interest and motivation for math.

\section{Relationship Between the BECOMA-On Results and Sex}

The item responses are given below for each item by students' sex: Table 2.

Table 2 demonstrated differences between the sexes which made it necessary to continue with the analysis to determine statistical significance. For example, item 29 was answered correctly by more girls than boys, despite the participating sample of girls being smaller. We performed a $t$ test to examine the results in more depth: Table 3.

As Table 3 shows, the mean score for the overall test battery was $35.18(\mathrm{SD}=10.08)$ for boys. and $34.44(\mathrm{SD}=9.22)$ for girls. Comparison testing showed that there were statistically significant differences between the sexes. Boys scored higher than girls in items $9,15,16,17,18,19,20,22,25,26,27$, and the Total score. While girls scored higher in items 7, 8, 12, 13, 23, and 30. It was notable that boys scored higher than girls in 5 of 
TABLE 2 | Frequencies for each item response by sex.

\begin{tabular}{|c|c|c|c|c|c|c|}
\hline \multirow[t]{2}{*}{ Items } & \multicolumn{3}{|c|}{ Boys } & \multicolumn{3}{|c|}{ Girls } \\
\hline & 0 & 1 & 2 & 0 & 1 & 2 \\
\hline IT 1 & 498 & 356 & 1148 & 397 & 334 & 1062 \\
\hline IT 2 & 710 & 753 & 539 & 634 & 685 & 474 \\
\hline IT 3 & 640 & 492 & 870 & 524 & 462 & 807 \\
\hline IT 4 & 301 & 421 & 1280 & 283 & 346 & 1164 \\
\hline IT 5 & 273 & 415 & 1314 & 220 & 360 & 1213 \\
\hline IT 6 & 211 & 660 & 1131 & 196 & 552 & 1045 \\
\hline IT 7 & 223 & 468 & 1311 & 170 & 335 & 1288 \\
\hline IT 8 & 432 & 520 & 1050 & 334 & 447 & 1012 \\
\hline IT 9 & 553 & 582 & 867 & 543 & 542 & 708 \\
\hline IT 10 & 701 & 720 & 581 & 658 & 634 & 501 \\
\hline IT 11 & 1021 & 465 & 516 & 936 & 394 & 463 \\
\hline IT 12 & 527 & 152 & 1323 & 428 & 101 & 1264 \\
\hline IT 13 & 290 & 254 & 1458 & 235 & 182 & 1376 \\
\hline IT 14 & 196 & 374 & 1432 & 160 & 332 & 1301 \\
\hline IT 15 & 514 & 719 & 769 & 567 & 807 & 419 \\
\hline IT 16 & 720 & 765 & 517 & 827 & 642 & 324 \\
\hline IT 17 & 769 & 740 & 493 & 766 & 738 & 289 \\
\hline IT 18 & 442 & 864 & 696 & 513 & 783 & 497 \\
\hline IT 19 & 455 & 870 & 677 & 490 & 853 & 450 \\
\hline IT 20 & 629 & 409 & 964 & 642 & 334 & 817 \\
\hline IT 21 & 977 & 355 & 670 & 930 & 300 & 563 \\
\hline IT 22 & 399 & 149 & 1454 & 463 & 103 & 1227 \\
\hline IT 23 & 695 & 385 & 922 & 548 & 331 & 914 \\
\hline IT 24 & 700 & 488 & 814 & 640 & 486 & 667 \\
\hline IT 25 & 422 & 550 & 1030 & 437 & 492 & 864 \\
\hline IT 26 & 547 & 905 & 550 & 570 & 750 & 473 \\
\hline IT 27 & 746 & 135 & 1121 & 798 & 119 & 876 \\
\hline IT 28 & 1072 & 756 & 174 & 924 & 718 & 151 \\
\hline IT 29 & 588 & 906 & 508 & 515 & 751 & 527 \\
\hline IT 30 & 494 & 578 & 930 & 389 & 442 & 962 \\
\hline Total & 16745 & 16206 & 27109 & 15737 & 14355 & 23698 \\
\hline
\end{tabular}

the 6 items in the Logical numerical series tests (items 14-19) and in 4 of the 6 items in the Conventional units test (items 2227). Whereas girls scored statistically significantly higher in the Geometric properties test (items 12 and 13).

To corroborate these differences between sexes for each of the Evaluation Tests (ET) in which each item is integrated, a $t$-test was carried out with the following results: Table 4.

In Table 4, statistically significant differences have been observed in several of the evaluation tests. In favor of men, in tests 4 or Logical numerical series, $p<0.001,5$ or Discovering algorithms, $p<0.01$, and 6 or Conventional units, $p<0.001$. In favor of women, in tests 3 or Geometric properties, $p<0.01$, and 7 or Logical series of figures, $p<0.01$.

\section{Relationship Between the BECOMA-On Results, Sex and Self-Efficacy Regarding Completing the Test Battery}

The first step in the analysis of this relationship was to examine the frequencies and corresponding percentages: Table 5.
TABLE $3 \mid t$ test for independent samples by sex.

\begin{tabular}{|c|c|c|c|c|c|c|c|c|}
\hline \multirow[t]{2}{*}{ Items } & \multicolumn{2}{|c|}{ Boys } & \multicolumn{2}{|c|}{ Girls } & \multirow[t]{2}{*}{$t$} & \multirow[t]{2}{*}{ df } & \multirow[t]{2}{*}{$p$} & \multirow[t]{2}{*}{ d } \\
\hline & $\mathbf{M}$ & SD & $\mathbf{M}$ & SD & & & & \\
\hline IT 1 & 1.32 & 0.85 & 1.37 & 0.82 & 1.70 & 3793 & 0.089 & 0.06 \\
\hline IT 2 & 0.91 & 0.78 & 0.91 & 0.79 & -0.15 & 3793 & 0.881 & 0.00 \\
\hline IT 3 & 1.11 & 0.86 & 1.16 & 0.85 & 1.55 & 3793 & 0.122 & 0.06 \\
\hline IT 4 & 1.49 & 0.74 & 1.49 & 0.75 & 1.00 & 3793 & 0.923 & 0.00 \\
\hline IT 5 & 1.52 & 0.72 & 1.55 & 0.70 & 1.46 & 3793 & 0.145 & 0.04 \\
\hline IT 6 & 1.46 & 0.68 & 1.47 & 0.68 & 0.63 & 3793 & 0.528 & 0.01 \\
\hline IT 7 & 1.54 & 0.69 & 1.62 & 0.65 & 3.68 & 3793 & $0.000^{\star \star \star}$ & 0.12 \\
\hline IT 8 & 1.31 & 0.80 & 1.38 & 0.78 & 2.70 & 3793 & $0.007^{\star \star}$ & 0.09 \\
\hline IT 9 & 1.16 & 0.83 & 1.09 & 0.83 & -2.41 & 3793 & $0.016^{\star}$ & 0.08 \\
\hline IT 10 & 0.94 & 0.80 & 0.91 & 0.80 & -1.06 & 3793 & 0.288 & 0.04 \\
\hline IT 11 & 0.75 & 0.84 & 0.74 & 0.84 & -0.42 & 3793 & 0.673 & 0.01 \\
\hline IT 12 & 1.40 & 0.88 & 1.47 & 0.85 & 2.44 & 3793 & $0.015^{\star}$ & 0.08 \\
\hline IT 13 & 1.58 & 0.73 & 1.64 & 0.70 & 2.27 & 3793 & $0.023^{\star}$ & 0.08 \\
\hline IT 14 & 1.62 & 0.66 & 1.64 & 0.64 & 0.90 & 3793 & 0.369 & 0.03 \\
\hline IT 15 & 1.13 & 0.79 & 0.92 & 0.74 & -8.43 & 3793 & $0.000^{\star \star \star}$ & 0.27 \\
\hline IT 16 & 0.90 & 0.78 & 0.72 & 0.75 & -7.19 & 3793 & $0.000^{\star \star \star}$ & 0.23 \\
\hline IT 17 & 0.86 & 0.78 & 0.73 & 0.72 & -5.23 & 3793 & $0.000^{\star \star \star}$ & 0.17 \\
\hline IT 18 & 1.13 & 0.74 & 0.99 & 0.75 & -5.59 & 3793 & $0.000^{\star \star \star}$ & 0.19 \\
\hline IT 19 & 1.11 & 0.74 & 0.98 & 0.72 & -5.58 & 3793 & $0.000^{\star \star \star}$ & 0.18 \\
\hline IT 20 & 1.17 & 0.88 & 1.10 & 0.90 & -2.42 & 3793 & $0.016^{\star}$ & 0.08 \\
\hline IT 21 & 0.85 & 0.89 & 0.80 & 0.89 & -1.77 & 3793 & 0.077 & 0.06 \\
\hline IT 22 & 1.53 & 0.81 & 1.43 & 0.87 & -3.70 & 3793 & $0.000^{\star \star \star}$ & 0.12 \\
\hline IT 23 & 1.11 & 0.89 & 1.20 & 0.88 & 3.15 & 3793 & $0.002^{\star \star}$ & 0.10 \\
\hline IT 24 & 1.06 & 0.87 & 1.02 & 0.85 & -1.50 & 3793 & 0.135 & 0.05 \\
\hline IT 25 & 1.30 & 0.80 & 1.24 & 0.82 & -2.50 & 3793 & $0.012^{\star}$ & 0.07 \\
\hline IT 26 & 1.00 & 0.74 & 0.95 & 0.76 & -2.28 & 3793 & $0.023^{*}$ & 0.07 \\
\hline IT 27 & 1.19 & 0.95 & 1.04 & 0.97 & -4.63 & 3793 & $0.000^{\star \star \star}$ & 0.16 \\
\hline IT 28 & 0.55 & 0.65 & 0.57 & 0.64 & 0.83 & 3793 & 0.407 & 0.03 \\
\hline IT 29 & 0.96 & 0.74 & 1.01 & 0.76 & 1.91 & 3793 & 0.056 & 0.07 \\
\hline IT 30 & 1.22 & 0.82 & 1.32 & 0.81 & 3.86 & 3793 & $0.000^{\star \star \star}$ & 0.12 \\
\hline Total & 35.18 & 10.08 & 34.44 & 9.22 & -2.34 & 3793 & $0.019^{*}$ & 0.08 \\
\hline
\end{tabular}

*Significant at 5\% $(p<0.05) .{ }^{*}$ Significant at $1 \%(p<0.01) .{ }^{* * *}$ Significant at $0.01 \%$ $(p<0.001)$.

Table 5 shows two notable tendencies. Firstly, girls chose selfefficacy scores of 4, 5, and 6 more than the boys. Secondly, more boys than girls rated themselves with self-efficacy scores of 7, 8, 9, and 10. This is shown graphically below: Figure $\mathbf{1}$.

These results required deeper analysis to examine possible statistically significant differences. The boys' mean score was 7.39 $(\mathrm{SD}=1.96)$. and the girls' was $6.92(\mathrm{SD}=1.99)$. The $t$ test gave a value of $-7.39 . p<0.001$ and $d=0.24$. It confirm the existence of statistically significant differences. After continuing to study these differences by means of a regression analysis with a view to establishing the predictive capacity of self-efficacy depending on the sex of schoolchildren, the following results have appeared: Table 6.

It has been observed that the contrast made by analysis of variance has given a value of 54.67 (the value of $t$ squared has been 54.61), obtaining a significance of $p<0.001$. The estimating function of the regression model has been: $\dot{Y}=6.92+0.47 \mathrm{X}$. The predicted score for self-efficacy men will be $\dot{Y}=7.39$, for women $\dot{Y}=6.92$. 
TABLE 4 | $t$ test for independent samples by sex for each evaluation tests.

\begin{tabular}{|c|c|c|c|c|c|c|c|c|}
\hline \multirow{2}{*}{$\begin{array}{l}\text { Evaluation } \\
\text { Tests }\end{array}$} & \multicolumn{2}{|c|}{ Boys } & \multicolumn{2}{|c|}{ Girls } & \multirow[t]{2}{*}{$t$} & \multirow[t]{2}{*}{ df } & \multirow[t]{2}{*}{$p$} & \multirow[t]{2}{*}{$d$} \\
\hline & $\mathbf{M}$ & SD & $\mathbf{M}$ & SD & & & & \\
\hline $\begin{array}{l}\text { ET1 } \\
\text { (IT 1-5) }\end{array}$ & 6.36 & 2.20 & 6.48 & 2.17 & 1.71 & 3793 & 0.087 & 0.05 \\
\hline $\begin{array}{l}\text { ET2 } \\
\text { (IT 6-11) }\end{array}$ & 7.16 & 3.27 & 7.22 & 3.22 & 0.56 & 3793 & 0.573 & 0.02 \\
\hline $\begin{array}{l}\text { ET3 } \\
\text { (IT 12-13) }\end{array}$ & 2.98 & 1.25 & 3.10 & 1.19 & 3.06 & 3793 & $0.002^{\star \star}$ & 0.10 \\
\hline $\begin{array}{l}\text { ET4 } \\
\text { (IT 14-19) }\end{array}$ & 6.74 & 3.08 & 5.98 & 2.67 & -8.16 & 3793 & $0.000^{\star \star \star}$ & 0.26 \\
\hline $\begin{array}{l}\text { ET5 } \\
\text { (IT 20-21) }\end{array}$ & 2.01 & 1.41 & 1.89 & 1.41 & -2.64 & 3793 & $0.008^{\star \star}$ & 0.09 \\
\hline $\begin{array}{l}\text { ET6 } \\
\text { (IT 22-27) }\end{array}$ & 7.19 & 2.73 & 6.87 & 2.64 & -3.63 & 3793 & $0.000^{\star \star \star}$ & 0.12 \\
\hline $\begin{array}{l}\text { ET7 } \\
\text { (IT 28-30) }\end{array}$ & 2.73 & 1.54 & 2.90 & 1.55 & 3.31 & 3793 & $0.001^{\star \star}$ & 0.11 \\
\hline
\end{tabular}

*Significant at 5\% $(p<0.05) .{ }^{* *}$ Significant at $1 \%(p<0.01) .{ }^{* * *}$ Significant at $0.01 \%$ $(p<0.001)$.

TABLE $\mathbf{5}$ | Self-efficacy in completing the test battery by sex.

\begin{tabular}{|c|c|c|c|c|c|c|}
\hline \multirow[t]{2}{*}{ Self-efficacy } & \multicolumn{2}{|c|}{ Boys } & \multicolumn{2}{|c|}{ Girls } & \multicolumn{2}{|c|}{ Total } \\
\hline & $f$ & $\%$ & $f$ & $\%$ & $f$ & $\%$ \\
\hline 0 & 24 & 0.63 & 28 & 0.74 & 52 & 1.37 \\
\hline 1 & 14 & 0.37 & 12 & 0.32 & 26 & $0.6 s$ \\
\hline 2 & 16 & 0.42 & 28 & 0.74 & 44 & 1.16 \\
\hline 3 & 30 & 0.79 & 39 & 1.03 & 69 & 1.82 \\
\hline 4 & 55 & 1.45 & 67 & 1.77 & 122 & 3.21 \\
\hline 5 & 150 & 3.95 & 190 & 5.01 & 340 & 8.96 \\
\hline 6 & 218 & 5.74 & 237 & 6.25 & 455 & 11.99 \\
\hline 7 & 421 & 11.09 & 413 & 10.88 & 834 & 21.98 \\
\hline 8 & 477 & 12.57 & 430 & 11.33 & 907 & 23.90 \\
\hline 9 & 345 & 9.09 & 240 & 6.32 & 585 & 15.42 \\
\hline 10 & 252 & 6.64 & 109 & 2.87 & 361 & 9.51 \\
\hline Total & 2002 & 52.75 & 1793 & 47.25 & 3795 & 100.00 \\
\hline
\end{tabular}

\section{Relationship Between the BECOMA-On Results, Sex, and Interest and Motivation for Math}

Table 7 gives the frequencies and percentages for this variable: Table 7.

Table 7 shows that the results were similar for the options chosen. with the exception of the highest scores. More girls gave themselves a score of 8 than boys, and more boys gave themselves scores of 10. Figure 2 shows this difference graphically: Figure 2.

It was necessary to analyze these results more deeply. The boys' mean score was $7.94(\mathrm{SD}=2.38)$, and the girls' mean score was $7.47(\mathrm{SD}=2.37)$. The $t$ test produced an index of $-6.09, p<0.001$ and $d=0.20$. It confirm the existence of statistically significant differences. With the aim of deepening these differences, a regression analysis has been carried out to observe the predictive capacity of interest and motivation toward

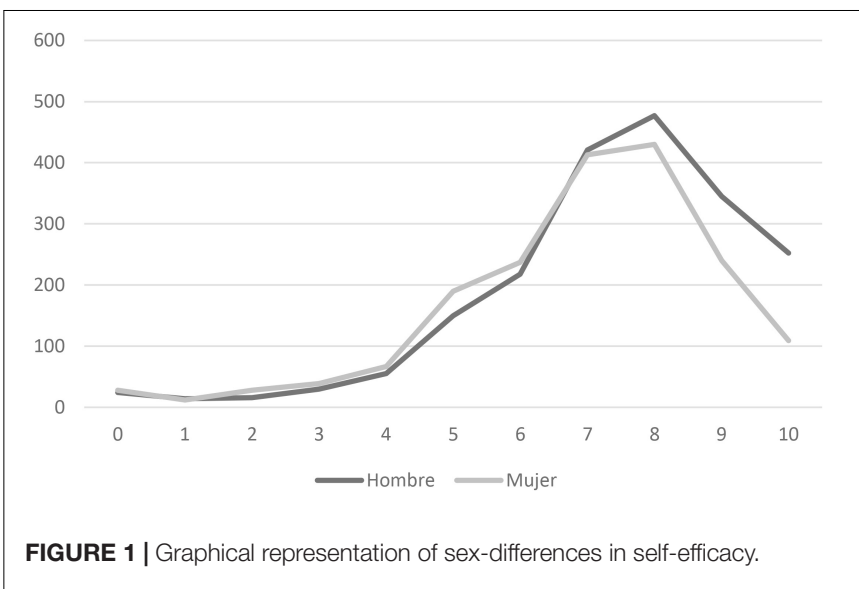

TABLE 6 | Regression analysis between sex and self-efficacy variables.

Model summary

\begin{tabular}{ccccc}
\hline Model & $\boldsymbol{R}$ & $\boldsymbol{R}$ square & $\begin{array}{c}\text { Adjusted } \\
\text { R squared }\end{array}$ & $\begin{array}{c}\text { Std. error of } \\
\text { the estimate }\end{array}$ \\
\hline 1 & 0.12 & 0.01 & 0.01 & 1.97
\end{tabular}

\begin{tabular}{|c|c|c|c|c|c|c|}
\hline 1 & 0.12 & 0.01 & & 0.01 & & 1.97 \\
\hline \multicolumn{7}{|c|}{ ANOVA } \\
\hline & Model & $\begin{array}{l}\text { Sum of } \\
\text { squares }\end{array}$ & df & $\begin{array}{l}\text { Mean } \\
\text { square }\end{array}$ & $F$ & $p$ \\
\hline \multirow[t]{3}{*}{1} & Regression & 212.94 & 1 & 212.94 & 54.67 & $0.000^{\star \star \star}$ \\
\hline & Residual & 14775.11 & 3793 & 3.89 & & \\
\hline & Total & 14988.05 & 3794 & & & \\
\hline
\end{tabular}

Coefficients

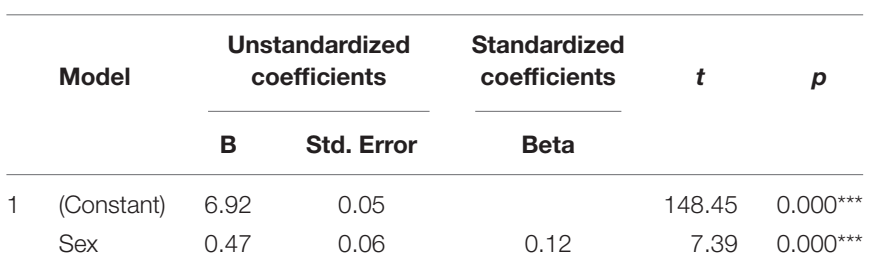

${ }^{*}$ Significant at $5 \%(p<0.05) .{ }^{* *}$ Significant at $1 \%(p<0.01) .{ }^{* * *}$ Significant at $0.01 \%$ $(p<0.001)$.

Mathematics according to the sex of schoolchildren, these results have been achieved: Table 8 .

This table has reflected the contrast made through analysis of variance with a value of 37.14 (the value of $t$ squared has been 37.10 ), reaching a significance of $p<0.001$. The estimating function of the regression model has been: $\dot{Y}=7.47+0.47 \mathrm{X}$. The expected score for men in interest and motivation will be $\dot{Y}=7.94$, for women $\dot{Y}=7.47$.

\section{DISCUSSION}

One of the basic premises of educational systems is the empowerment of human capital. The integrated development of each person encourages a country's social, economic and cultural progress. Compulsory schooling is a key time to make the school population participants in learning. Co-education is key work in 
TABLE 7 | Interest and motivation for math by sex.

\begin{tabular}{|c|c|c|c|c|c|c|}
\hline \multirow{2}{*}{$\begin{array}{l}\text { Interest and } \\
\text { motivation }\end{array}$} & \multicolumn{2}{|c|}{ Boys } & \multicolumn{2}{|c|}{ Girls } & \multicolumn{2}{|c|}{ Total } \\
\hline & $f$ & $\%$ & $f$ & $\%$ & $f$ & $\%$ \\
\hline 0 & 53 & 1.40 & 33 & 0.87 & 86 & 2.27 \\
\hline 1 & 13 & 0.34 & 26 & 0.69 & 39 & 1.03 \\
\hline 2 & 17 & 0.45 & 35 & 0.92 & 52 & 1.37 \\
\hline 3 & 46 & 1.21 & 36 & 0.95 & 82 & 2.16 \\
\hline 4 & 45 & 1.19 & 73 & 1.92 & 118 & 3.11 \\
\hline 5 & 110 & 2.90 & 129 & 3.40 & 239 & 6.30 \\
\hline 6 & 137 & 3.61 & 160 & 4.22 & 297 & 7.83 \\
\hline 7 & 220 & 5.80 & 211 & 5.56 & 431 & 11.36 \\
\hline 8 & 306 & 8.06 & 361 & 9.51 & 667 & 17.58 \\
\hline 9 & 380 & 10.01 & 364 & 9.59 & 744 & 19.60 \\
\hline 10 & 675 & 17.79 & 365 & 9.62 & 1.040 & 27.40 \\
\hline Total & 2002 & 52.75 & 1793 & 47.25 & 3795 & 100.00 \\
\hline
\end{tabular}

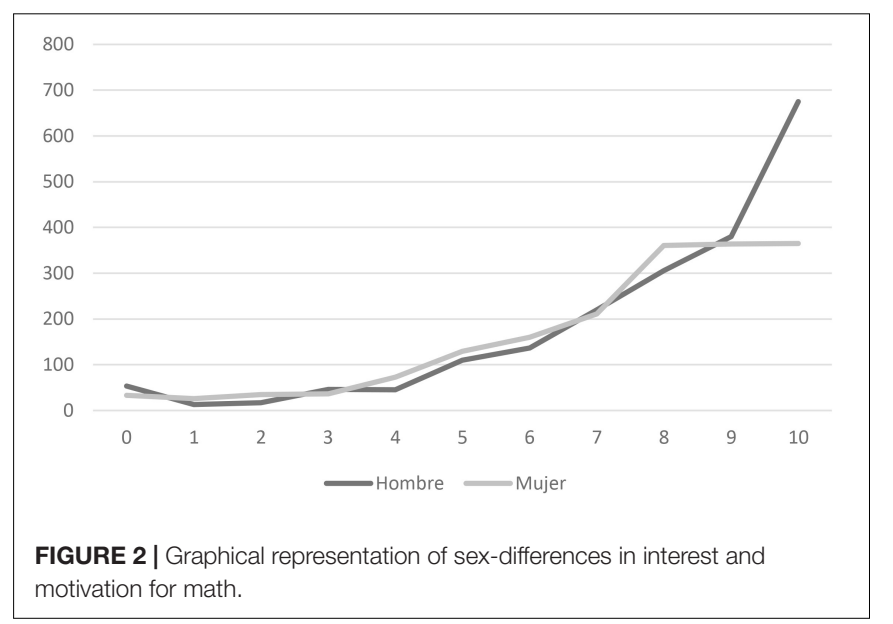

schools, all students must have the same teaching and learning processes in equal conditions and with equal opportunities, avoiding the discrimination that occasionally coexists with the attempt to offer quality education (Gallardo-López et al., 2020). Differences between sexes may be avoided if suitable measures are put in place (Ministerio de Educación y Formación Profesional, 2019b). In this regard, educational tasks in the curriculum based on scientific-technical skills, such as STEAM (Science, Technology, Engineering, Art and Mathematics). May be an interesting option for encouraging equality between the sexes in the classroom (Crespo-García, 2019).

This is justified by the results from our study. There were statistically significant differences between the sexes in the participating sample. In almost all of the items of the Logical numerical series, and Conventional units sub-testes the boys exhibited higher scores. In contrast, girls scored higher in the items making up the Geometric properties test. In the analysis of the results according to each evaluation test, there are also differences between the sexes, with better results being observed for men in tests with arithmetic content and management of units of measurement, and for women in tests with geometric content. These effects may indicate that sex differences, noted
TABLE 8 | Regression analysis between sex and interest and motivation toward Mathematics.

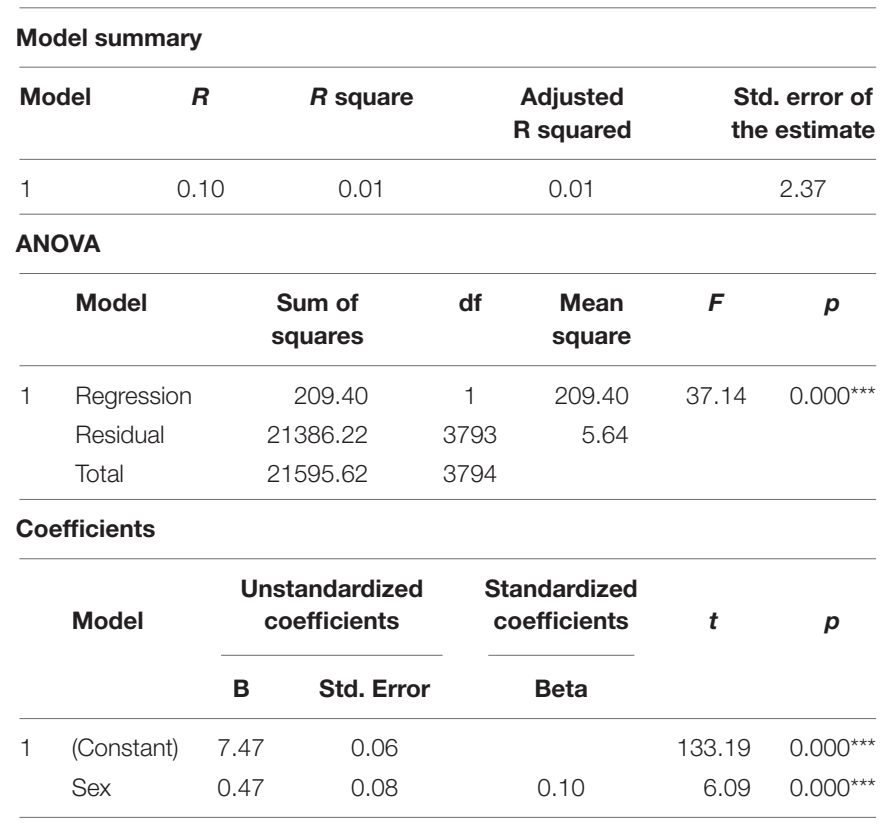

$\bar{*}$ Significant at 5\% $(p<0.05) .{ }^{* * \text { Significant at } 1 \%(p<0.01) .{ }^{* * *} \text { Significant at } 0.01 \%}$ $(p<0.001)$.

in various studies, may be more linked to results in specific sub-areas of math.

In addition, when comparing the results from boys and girls regarding self-efficacy about completing the test battery, there were statistically significant $(p<0.001)$ differences. Girls selected options $4-6$ in the self-efficacy scale more than boys, and boys selected the higher score, 7-10, more than girls. The estimating function of the regression model has been: $\dot{Y}=6.92+0.47 \mathrm{X}$. This is despite there being items in which each sex scored higher than the other. In education, beliefs of self-efficacy affect motivation, persistence, and school success (Zalazar et al., 2011; Rosário et al., 2012; Huéscar-Hernández et al., 2020), and there are also social factors (Ruiz, 2005).

The last variable analyzed was students' interest and motivation for math according to sex. The results were similar between the two sexes, except for the fact that more girls gave themselves scores of 8 than boys, and more boys gave themselves scores of 10 than girls, both statistically significant differences $(p<0.001)$. This was despite some girls outperforming boys, and some boys outperforming girls. The estimating function of the regression model has been: $\dot{Y}=7.47+0.47 \mathrm{X}$. These results are in line with findings from other studies (Bazán and Aparicio, 2006; Molera, 2012; Instituto Nacional de Evaluación Educativa, 2013; Mato et al., 2014; Ministerio de Educación y Formación Profesional, 2019b). In addition, this issue may be affected by changes in educational stages, with the transition between primary and secondary school, when attitudes toward math increasingly decline (Mato et al., 2014) and there is the appearance of a lack of interest, motivation, value and faith in ones' own abilities (Mato, 2010).

Learning math makes educational sense when the knowledge learned in this area is used in the schoolchild's normal 
surroundings. In this regard, the value placed on math by the individual, and attitudinal factors are central in learning math. Pleasure in learning math leads to enjoyment for the learner, they perform well, and they find the content interesting (Tourón et al., 2012), as well as exhibiting better attitudes toward homework (Pan et al., 2013). In this way, educational practice must insist on the importance of these considerations or attitudes toward math, and be aware that occasionally the difference between the sexes can come from a discrepancy between what one does and what one could do, from the predisposition to learning rather than problems of attitude. It is unreasonable for the sex of schoolchildren to be a barrier to academic success in this subject. For the development of future research on sex using evaluation tests such as the one presented in this study, other variables could be included for a more exhaustive analysis such as, for example, academic performance, interest and motivation of the scholar toward Mathematics from the point of teaching view and / or academic self-concept. The number of questions for the collection of data related to the variables self-efficacy and interest and motivation in Mathematics will also be increased, with the aim of calculating internal consistency indices of the measurements made. We highlight some data to consider; $75.0 \%$ of undergraduates and $71.8 \%$ of graduates in Engineering and Architecture are men (Ministerio de Ciencia, Innovación y Universidades, 2019). In 2030 it is expected that $32 \%$ of women will reach tertiary education, and $27 \%$ of men. Currently the number of women aged 25-64 who have higher education qualifications is $15 \%$ higher than the number of men who have those qualifications in Spain (Ministerio de Educación y Formación Profesional, 2019a). Logically, the achievement of personal, social and school wellbeing is essential in educational processes.

\section{REFERENCES}

Barbero, M. I., Holgado, F. P., Vila, E., and Chacón, S. (2007). Actitudes, hábitos de estudio y rendimiento en Matemáticas: diferencias por género. Psicothema 19, 413-421.

Bazán, J. L., and Aparicio, A. S. (2006). Las actitudes hacia la MatemáticaEstadística dentro de un modelo de aprendizaje. Revist. Semes. Depart. Educ. $25,1-12$.

Beltrán, J. A., and Pérez, L. (1994). Estudio Experimental del Autoconcepto Académico en Alumnos de Altas Capacidades a Través de la Escala E.D.D.A. Madrid: Universidad Complutense.

Benavides, M. (2008). Caracterización de Sujetos con Talento en Resolución de Problemas de Estructura Multiplicativa. Ph. D. Thesis, University of Granada, Granada.

Bennett, M. (1997). Self-estimates of ability in men and women. J. Soc. Psychol. 137, 540-541. doi: 10.1080/00224549709595475

Bian, L., Leslie, S. J., and Cimpian, A. (2017). Gender stereotypes about intellectual ability emerge early and influence children's interests. Science 355, 389-391. doi: 10.1126/science.aah6524

Botella, C., Rueda, S., López-Iñesta, E., and Marzal, P. (2019). Gender diversity in STEM disciplines: a multiple factor problem. Entropy 21, 1-17. doi: 10.3390/ e21010030

Chan, D. W. (2006). Perceived multiple intelligences among male and female chinese gifted students in hong kong: the structure of the student multiple intelligences profile. Gifted Child Q. 50, 325-338. doi: 10.1177/ 001698620605000405

Crespo-García, R. (2019). Género y STEM: un falso antagonismo. Univ. Verdad 75, 61-69. doi: 10.33324/uv.v1i75.215

\section{DATA AVAILABILITY STATEMENT}

The raw data supporting the conclusions of this article will be made available by the authors, without undue reservation.

\section{ETHICS STATEMENT}

The studies involving human participants were reviewed and approved by National Institute of Educational Technologies and Teacher Training (INTEF), the National University of Distance Education (UNED), and the University of Castilla-La Mancha (UCLM). Written informed consent to participate in this study was provided by the participants' legal guardian/next of kin.

\section{AUTHOR CONTRIBUTIONS}

RG-P designed the study, collected and analyzed the data, and wrote the manuscript. AP-R contributed to the interpretation of the data and wrote, revised, and refined the manuscript. RG-P and AP-R participated in sending the article to the journal. Both authors contributed to the article and approved the submitted version.

\section{FUNDING}

This study was supported by the National Institute of Educational Technologies and Teacher Training (INTEF), the National University of Distance Education (UNED), and the University of Castilla-La Mancha (UCLM).

Cueli, M., García, T., and González-Castro, P. (2013). Autorregulación y rendimiento académico en Matemáticas. Aula Abierta 41, 39-48.

Fox, L. H., and Denham, S. A. (1974). Values and Career Interests of Mathematically and Scientifically Precocious Youth. Baltimore, MD: The Johns Hopkins University Press.

Furnham, A., Clark, K., and Bailey, K. (1999). Sex differences in estimates of multiple intelligences. Eur. J. Pers. 13, 247-259. doi: 10.1002/(sici)10990984(199907/08)13:4<247::aid-per329>3.0.co;2-7

Gallardo-López, J. A., García-Lázaro, I., and Gallardo-Vázquez, P. (2020). Coeducación en el sistema educativo español: un puente para alcanzar la equidad y la justicia social. Braz. J. Dev. 6, 13092-13106. doi: 10.34117/bjdv 6n3-247

García-Perales, R. (2016). Sexo femenino y capacidades matemáticas: desempeño de los más capaces en pruebas de rendimiento matemático. Ensaio Aval. Polit. Públ. Educ. 24, 5-29. doi: 10.1590/s0104-4036201600010 0001

García-Perales, R., and Almeida, L. S. (2019). Programa de enriquecimiento para alumnado con alta capacidad: Efectos positivos para el currículum. Comunicar 60, 39-48. doi: 10.3916/C60-2019-04

González, R. M. (2019). Evaluación de estrategias formativas para mejorar las actitudes hacia las matemáticas en secundaria. Educ. Matemát. 31, 176-203. doi: 10.24844/em3101.07

Hadjar, A., Krolak-Schwerdt, S., Priem, K., and Glock, S. (2014). Gender and educational achievement. Educ. Res. 56, 117-125. doi: 10.1080/00131881.2014. 898908

Hernández, D., and Gutiérrez, M. (2014). El estudio de la alta capacidad intelectual en España: análisis de la situación actual. Revist. Educ. 364, 251-272. doi: 10. 4438/1988-592X-RE-2014-364-261 
Huang, C. C., Chen, Y., Jin, H., Stringham, M., Liu, C., and Oliver, C. (2020). Mindfulness, life skills, resilience, and emotional and behavioral problems for gifted low-income adolescents in China. Front. Psychol. 11:594. doi: 10.3389/ fpsyg.2020.00594

Huéscar-Hernández, E., Moreno-Murcia, J. A., Cid, L., Monteiro, D., and Rodrigues, F. (2020). Passion or perseverance? The effect of perceived autonomy support and grit on academic performance in college students. Int. J. Environ. Res. Public Health 17:2143. doi: 10.3390/ijerph17062143

Instituto Nacional de Evaluación Educativa (2013). PISA 2012: Informe Español. Volumen I: Resultados y contexto. Madrid: Ministerio de Educación.

Jaime, A., and Gutiérrez, A. (2017). "Investigacioìn sobre estudiantes con alta capacidad matemaitica," in Investigacioin en Educacioin Matemaitica XXI, eds J. M. Munpoz-Escolano, A. Arnal-Bailera, P. Beltraìn-Pellicer, M. L. Callejo, and J. Carrillo (Zaragoza: SEIEM), 71-89.

Jiménez, C. (2014). El Desarrollo del Talento: Educación y alta capacidad. Lección Inaugural del Curso Académico 2014-2015 de la UNED. Madrid: UNED.

Jiménez, C., and Baeza, M. A. (2012). Factores significativos del rendimiento excelente: PISA y otros estudios. Ensaio Aval. Polít. Públ. Educ. 20, 647-676. doi: 10.1590/s0104-40362012000400003

Jiménez, C., Murga, M. A., Gil, J. A., Téllez, J. A., and Paz, M. (2010). Hacia un modelo sociocultural explicativo del alto rendimiento y la alta capacidad: ámbito académico y capacidades personales. Revist. Educ. XX 1, 125-153. doi: 10.5944/educxx1.13.1.280

Kerr, B. (2000). "Guiding gifted girls and young women," in International Handbook of Giftedness and Talent, eds K. M. Heller, F. J. Mönks, R. J. Sternberg, and R. F. Subotnik (Oxford, UK: Pergamon Press), 649-657. doi: 10.1016/b978008043796-5/50046-2

Kruteskii, V. A. (1976). The Psychology of Mathematical Abilities in School Children. Chicago: University of Chicago Press.

Landau, E. (2003). El Valor de ser Superdotado. Madrid: Consejería de Educación.

Lehman, K. J., Sax, L. J., and Zimmerman, H. B. (2017). Women planning to major in computer science: who are they and what makes them unique? J. Comput. Sci. Educ. 26, 277-298. doi: 10.1080/08993408.2016.1271536

Llor, L., Ferrando, M., Ferrandiz, C., Hernández, D., Sainz, M., Prieto, M. D., et al. (2012). Inteligencias múltiples y alta habilidad. Aula Abierta 40, 27-38.

Mandelman, S. D., Tan, M., Aljughaiman, A. M., and Grigorenko, E. L. (2010). Intelectual gifteness: economic, political, cultural and psychological considerations. Learn. Indiv. Differ. 20, 286-297.

Mato, M. D. (2010). Mejorar las actitudes hacia las Matemáticas. Revist. Galego Portu. Psicol. Educ. 18, 19-32.

Mato, M. D., Espiñeira, E., and Chao, R. (2014). Dimensión afectiva hacia la matemática: resultados de un análisis en educación primaria. Revist. Invest. Educ. 32, 57-72. doi: 10.6018/rie.32.1.164921

McCullough, L. (2020). Proportions of women in STEM leadership in the academy in the USA. Educ. Sci. 10:1. doi: 10.3390/educsci10010001

Ministerio de Ciencia, Innovación y Universidades (2019). Datos y Cifras del Sistema Universitario Español. Publicación 2018-2019. Available online at: https: //cutt.ly/Ur3tBtD (accessed March 11, 2020).

Ministerio de Educación, Cultura y Deporte (2014). Marco General de la Evaluación de 3 er Curso de Educación Primaria. Available online at: https://cutt.ly/Ar3tX5u (accessed March 28, 2020).

Ministerio de Educación y Formación Profesional (2019a). Panorama de la Educación. Indicadores de la OCDE 2019. Available online at: https://cutt.ly/ 7r3tH4x (accessed May 7, 2020).

Ministerio de Educación y Formación Profesional (2019b). PISA 2018. Programa Para la Evaluación Internacional de los Estudiantes. Informe Español. Available online at: https://cutt.ly/zr3uTgk (accessed April 19, 2020).

Ministerio de Educación y Formación Profesional (2020). Datos Estadísticos Para Enseñanzas no Universitarias. Available online at: https://cutt.ly/Vr3tLkM (accessed March 24, 2020).
Molera, J. (2012). ¿Existe relación en la Educación Primaria entre los factores afectivos en las Matemáticas y el rendimiento académico? Estudios Sobre Educ. 23, 141-155.

Muñoz, J. M., and Mato, M. D. (2008). Análisis de las actitudes respecto a las Matemáticas en alumnos de ESO. Revist. Invest. Educ. 26, 209-226.

Nortes, R., and Nortes, A. (2020). Actitud hacia las matemáticas en el Grado de Maestro de Primaria. Revist. Electrón. Interuniv. Form. del Profesorado 23, 225-239. doi: 10.6018/reifop.348061

Organización para la Cooperación y el Desarrollo Económico (2009). Top of the Class. High Performers in Science in PISA 2006. París: OCDE.

Palacios, A., Arias, V., and Arias, B. (2014). Attitudes towards mathematics: construction and validation of a measurement instrument. Revist. Psicodidáctica 19, 67-91. doi: 10.1387/RevPsicodidact.8961

Pan, I., Regueiro, B., Ponte, B., Rodríguez, S., Piñeiro, I., and Valle, A. (2013). Motivación. implicación en los deberes escolares y rendimiento académico. Aula Abierta 41, 13-22.

Pasarín, M., Feijoo, M., Díaz, O., and Rodríguez, L. (2004). Evaluación del talento matemático en educación Secundaria. Revista Int. Faisca Altas Capacidades 11, 83-102.

Pérez, L., and Díaz, O. (1994). Bajo rendimiento académico y desintegración escolar en alumnos de altas capacidades. Revist. Int. Faisca Altas Capacidades $1,103-127$.

Pomar, C., Díaz, O., Sánchez, T., and Fernández, M. (2009). Habilidades matemáticas y verbales: diferencias de género en una muestra de $6^{\circ}$ de Primaria y $1^{\circ}$ de ESO. Revist. Int. Faisca Altas Capacidades 14, 14-26.

Reyes-Santander, P., and Karg, A. (2009). "Una aproximación al trabajo con niños especialmente dotados en Matemáticas," in Investigación en Educación Matemática XIII, eds M. J. González, M. T. González, and J. Murillo (Santander: SEIEM), 403-414.

Rosário, P., Lourenço, A., Paiva, O., Rodrigues, A., Valle, A., and Tuero-Herrero, E. (2012). Predicción del rendimiento en matemáticas: efecto de variables personales, socioeducativas y del contexto escolar. Psicothema 24, 289-295.

Ruiz, F. (2005). Influencia de la autoeficacia en el ámbito académico. Docencia Univ. 1, 1-16. doi: 10.19083/ridu.1.33

Sánchez, C., Fernández, M. C., Rojo, A., Sainz, M., Hernández, D., Ferrando, M., et al. (2008). Inteligencias múltiples y Superdotación. Sobredotação 9, $87-105$.

Suberviola, I. (2012). Coeducación: un derecho y un deber del profesorado. Revist. Electrón. Interuniv. Formación Profesorado 15, 59-67.

Tourón, J., Lizasoaín, L., Castro, M., and Navarro, E. (2012). “Alumnos de alto. medio y bajo rendimiento en Matemáticas en TIMSS. Estudio del impacto de algunos factores de contexto," in PIRLS-TIMSS 2011: Informe Español. Análisis Secundario 2, ed. Instituto Nacional de Evaluación Educativa (Madrid: Ministerio de Educación, Cultura y Deporte), 187-215.

Unión Europea (2004). Puesta en Práctica del Programa de Trabajo Educación y Formación 2010. Bruselas: Comisión Europea.

Zalazar, M. F., Aparicio, M. M. D., Ramírez, C. M., and Garrido, S. J. (2011). Estudios preliminares de adaptación de la Escala de Fuentes de Autoeficacia para Matemáticas. Revist. Argent. Ciencias Comportamiento 3, 1-6.

Conflict of Interest: The authors declare that the research was conducted in the absence of any commercial or financial relationships that could be construed as a potential conflict of interest.

Copyright (C) 2020 Palomares-Ruiz and García-Perales. This is an open-access article distributed under the terms of the Creative Commons Attribution License (CC BY). The use, distribution or reproduction in other forums is permitted, provided the original author(s) and the copyright owner(s) are credited and that the original publication in this journal is cited, in accordance with accepted academic practice. No use, distribution or reproduction is permitted which does not comply with these terms. 